\title{
Leucine-Rich Repeats and Immunoglobulin-Like Domains Protein Family
}

National Cancer Institute

\section{Source}

National Cancer Institute. Leucine-Rich Repeats and Immunoglobulin-Like Domains

Protein Family. NCI Thesaurus. Code C122769.

\begin{abstract}
A family of membrane bound proteins comprised of 15 leucine-rich repeats that are flanked both $\mathrm{N}$ - and $\mathrm{C}$ - terminally by cysteine-rich regions, three C2-type immunog lobulin-like domains, a transmembrane domain, and a cytoplasmic tail. The members of this protein family may be involved in the suppression of growth factor receptor signaling.
\end{abstract}

